\title{
Hemorrhagic Schwannoma of the Cauda Equina: Case Report and Review of the Literature
}

\author{
Viscardo P. FABBRI, ${ }^{1}$ Filippo FRISO, ${ }^{2,3}$ Federico CHIARUCCI, ${ }^{1}$ \\ Laura Ludovica GramegnA, ${ }^{2,4}$ Francesco TONI, ${ }^{5}$ Maria P. FOSCHINI, ${ }^{1}$ \\ Sofia ASIOLI, ${ }^{1}$ Anna CREMONINI, ${ }^{1}$ and Nicola ACCIARRI ${ }^{3}$ \\ ${ }^{1}$ Department of Biomedical and Neuromotor Sciences, University of Bologna, Unit of \\ Anatomic Pathology, Bellaria Hospital, Bologna, Italy \\ ${ }^{2}$ Department of Biomedical and Neuromotor Sciences, University of Bologna, Bologna, Italy \\ ${ }^{3}$ IRCCS/Institute of Neurological Science of Bologna, Department of Neurologic Surgery, \\ Bellaria Hospital, Bologna, Italy \\ ${ }^{4}$ IRCCS/Institute of Neurological Science of Bologna, Unit of Functional and Molecular \\ Neuroimaging, Bellaria Hospital, Bologna, Italy \\ ${ }^{5}$ IRCCS/Institute of Neurological Science of Bologna, Unit of Neuradiology, Bellaria \\ Hospital, Bologna, Italy
}

\begin{abstract}
Spinal intradural hemorrhage is a rare event; the most common causes of spinal bleeding are traumas, medical therapy with anticoagulants and thrombolytics, vascular malformations, and congenital defects of coagulation. Rarely, spinal cord tumors may cause hemorrhage. Herein, we report the case of a patient with acute and quickly worsening lumbar pain: the neurological examination revealed a flaccid paraplegia caused by an intradural lesion extending on the right side of the spinal cord from T1 to L2 vertebral level. Pathological examination revealed an hemorrhagic schwannoma. Acute spinal subdural hemorrhage caused by spinal schwannomas is a very rare occurrence ( 29 cases only have been previously reported). Review of the literature with clinico-diagnostic features is presented, surgical treatment is explained, and pathological findings with possible etiopathogenesis of hemorrhage are described.
\end{abstract}

Keywords: spinal bleeding, hemorrhagic schwannoma, intradural schwannoma, flaccid paraplegia

\section{Introduction}

Schwannomas are benign, typically encapsulated, nerve sheath tumors, composed entirely of welldifferentiated Schwann cells. ${ }^{11}$ They arise in the transition zone between central and peripheral myelination of nerve sheath, displacing or invading the normal structure of a nerve trunk. Schwannomas are most often located in the head and neck region, or along the limbs. Spinal schwannomas usually present as intraspinal lesions (accounting for 30\%

Received June 18, 2020; Accepted November 12, 2020

Both Viscardo P. Fabbri and Filippo Friso equally contributed to the paper.

Copyright $@ 2021$ The Japan Neurosurgical Society

This work is licensed under a Creative Commons AttributionNonCommercial-NoDerivatives International License. of primary spinal tumor). ${ }^{2}$ The most common presenting symptoms are progressive lumbar pain and radiculopathy, or chronic neurological deficits. Rarely, they may present with symptoms due to hydrocephalus. ${ }^{3)}$ On very rare occasions, spinal schwannomas may cause subdural hemorrhage presenting with acute neurological deterioration. The purpose of this paper is to report a case of schwannoma of the cauda equina presenting with acute neurological dysfunction due to massive hemorrhage.

\section{Case Report}

A 57-year-old female with a past medical history of hypertension and obesity presented to an initial medical observation with acute and quickly worsening lumbar pain, associated with right lower limb weakness and bilateral impaired sensitivity with paraesthesia. There was no history of trauma or 
anticoagulation therapy. Five days after the onset of symptoms, the patient was referred to our Institution for a better diagnostic scrutiny, due to the rapid deterioration of clinical conditions. She was confused, agitated, and the neurological examination revealed a flaccid paraplegia with sensitive level around T11 dermatome and fecal and urinary incontinence. The patient was submitted to a spinal magnetic resonance imaging (MRI) that showed an intradural lesion extending to the right side of the spinal cord from T1 to L2 vertebral level. The lesion appeared heterogeneously hyperintense on T2-weighted and hypointense on T2*-weighted gradient echo; the mass demonstrated patchy enhancement after
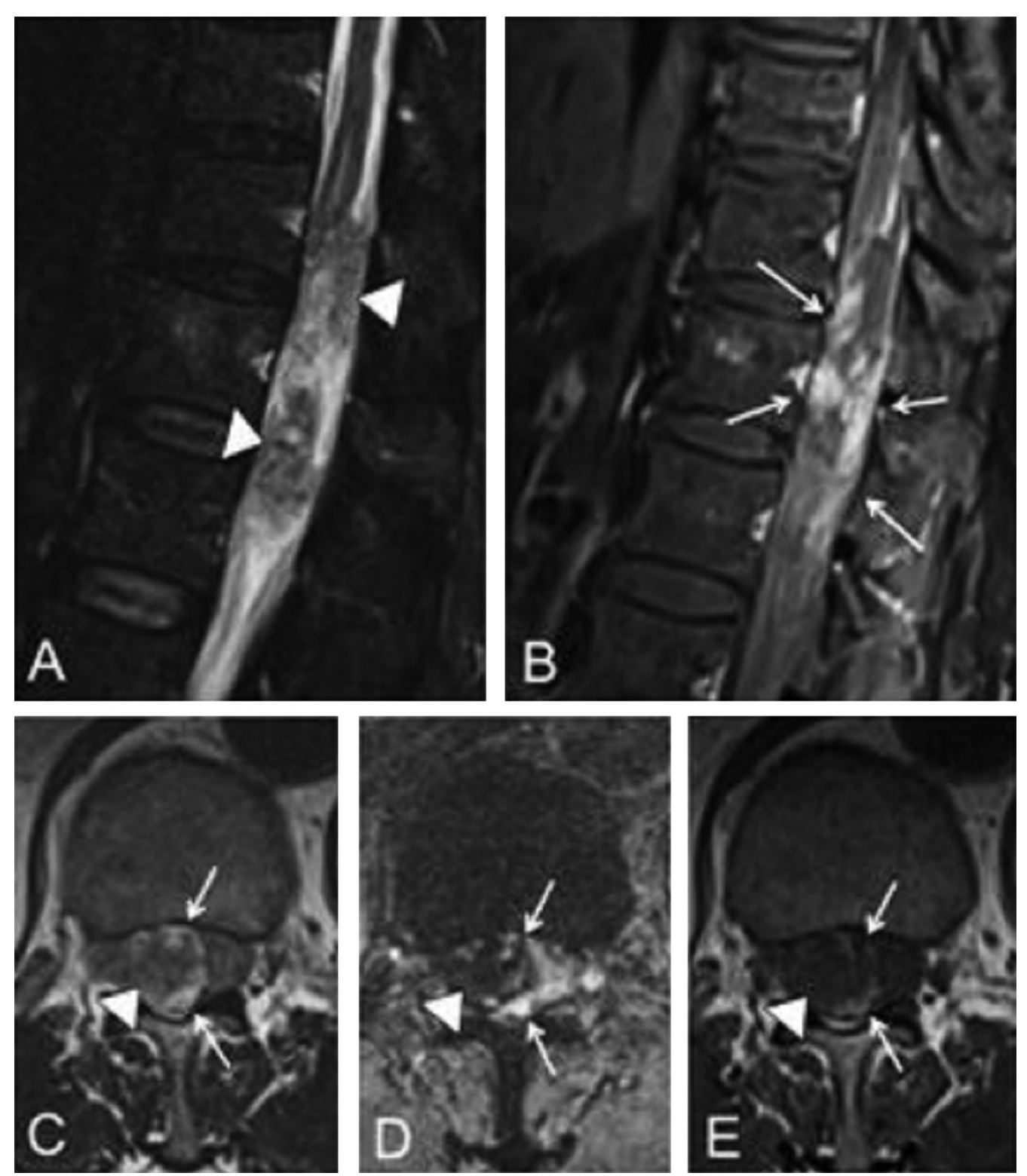

Fig. 1 Preoperative MRI. (A) Sagittal STIR T2-weighted and (B) sagittal T1-weighted post-gadolinium sequences showing an intra-dural extramedullary mass displacing anteriorly the conus medullaris. The lesion appears inhomogeneously hyperintense in STIR T2, with areas of reduced signal representing hemorrhagic components (arrowhead in A), and patchy enhancement after contrast medium administration (white arrows in B). (C) Axial T2-weighted, (D) axial T2*-weighted and E axial T1-weighted post-gadolinium sequences show the mass enlarging the vertebral canal and shifting on the left side the spinal cord. The hemorrhagic portion (arrowhead) is better depicted in the sequence susceptible to paramagnetic effect (more evident loss of signal due to deoxyhemoglobin in D), and is surrounded by a thin area of T2 hyperintensity (white arrows in C and D) with patchy contrast enhancement (white arrows in E). MRI: magnetic resonance imaging, STIR: short time inversion recovery. 
contrast medium administration (Figs. 1A-1E). The lesion was considered intradural and extramedullary since it caused a left ward deviation of the spinal cord. Moreover, the diameter of the spinal canal was slightly increased at T12 level, suggesting the slow growing nature of the mass.

Bleeding due to intradural extramedullary hemorrhagic neoplasm was proposed.

Due to the severe neurological conditions, surgical therapy was delivered as an emergency. The patient was submitted in less than 24 hours to a decompressive T11-L1 laminectomy, exposing the dural sac (Figs. 2A-2C), which was extremely swollen, with ectatic vessels around. The dura was opened applying microsurgical technique and a large brownish mass was detected inside the roots of the cauda equina (Fig. 2D). The mass was attached to an ectatic vessel perforating the dura mater. A large hematoma was present below the lesion, enveloping the nervous structures. After careful removal of hemorrhagic clots around the roots of the cauda equina, the mass was totally resected detaching it from the abnormal neurovascular pedicle. The removed lesion was submitted for histological examination.

On gross examination, the specimen consisted of multiple fragments of brownish tissue measuring 0.5-2 cm. All fragments were formalin fixed and paraffin embedded (FFPE) according to routine procedures.
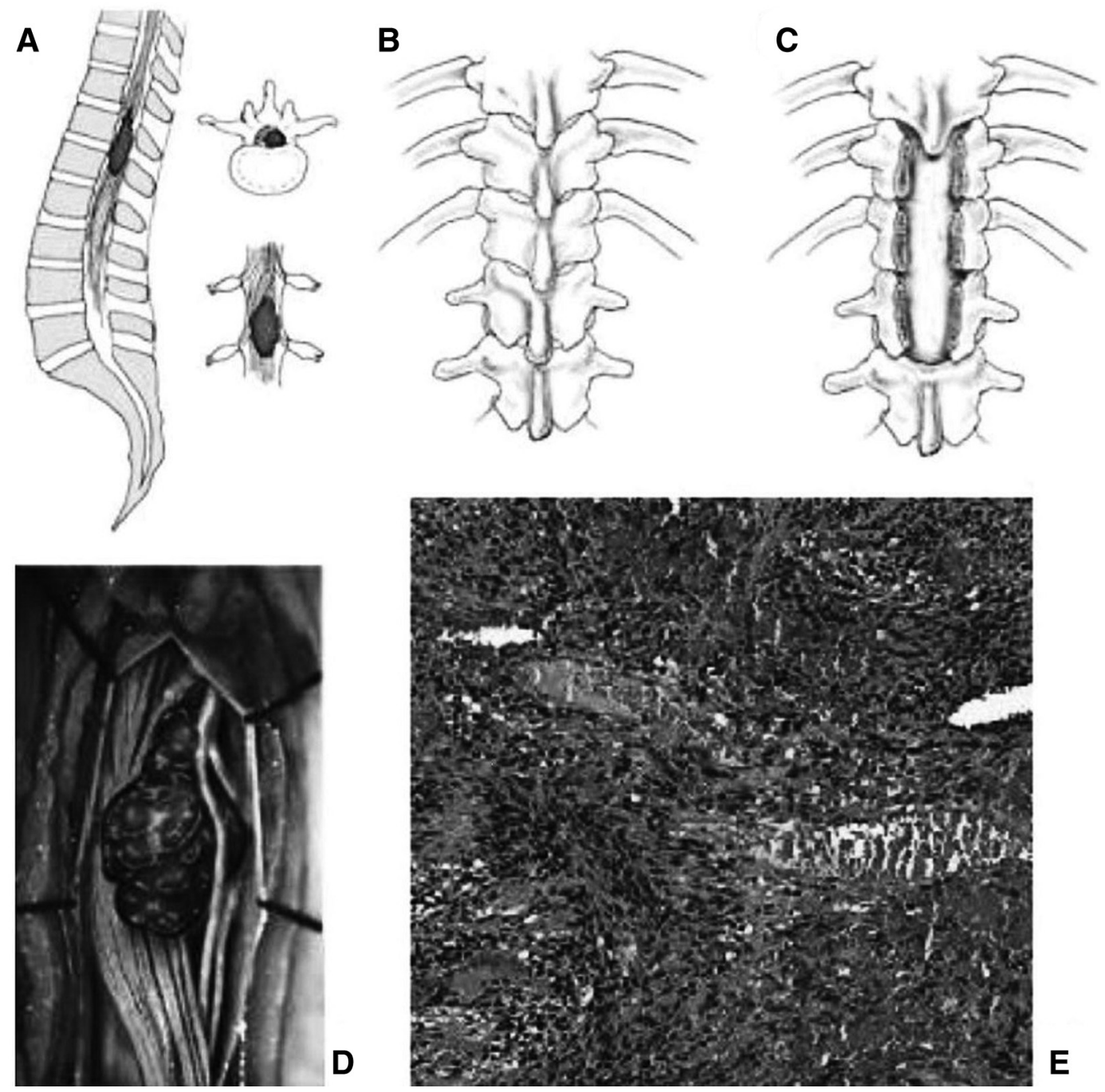

Fig. 2 Scheme of the lesion: Surgical approach: decompressive T11-L1 laminectomy and exposure of an extremely swollen dural sac, with ectatic vessels around (A-C). The mass presented intratumoral hemorrhage and displaced the roots of the cauda equina (D). Neoplastic spindle-cells, ectatic vessels, and diffuse intertumoral hemorrhage with hematoxylin-eosin (E).

NMC Case Report Journal Vol. 8, 2021 

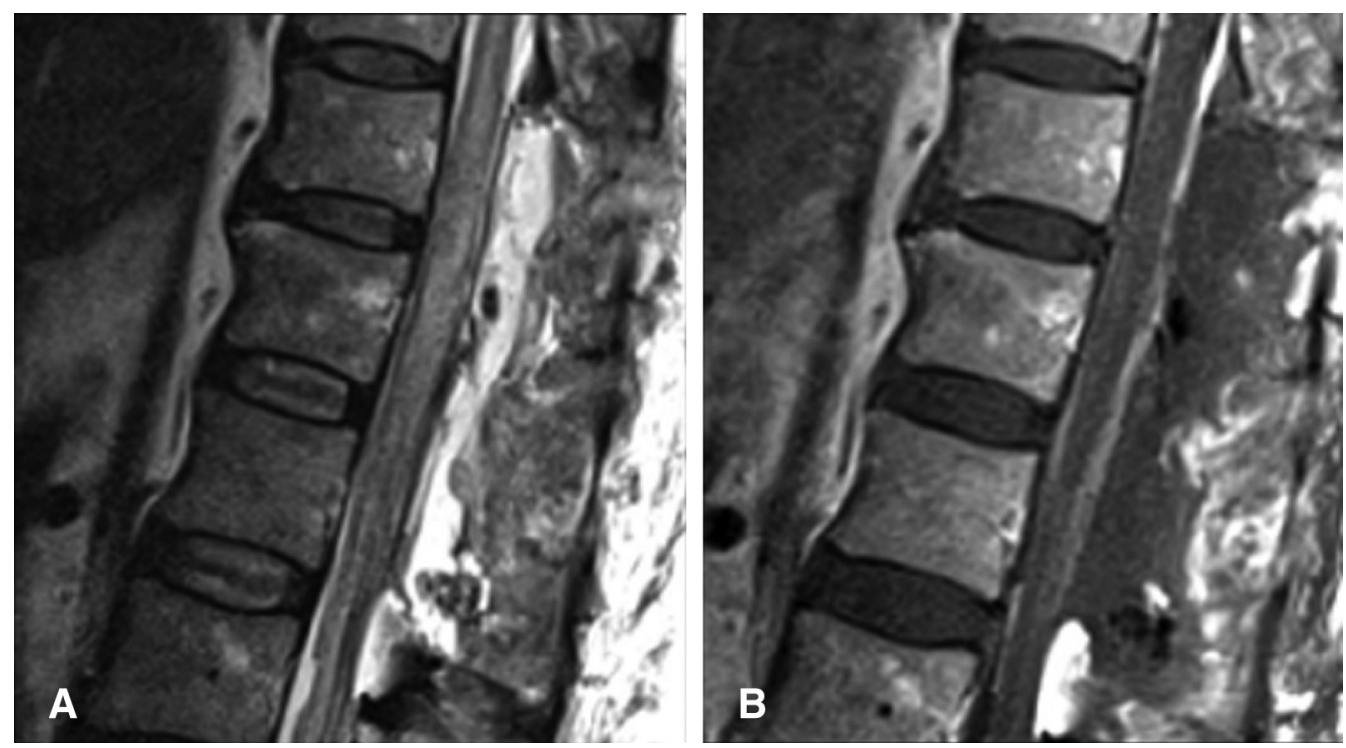

Fig. 3 Postoperative MRI. (A) Sagittal T2-weighted and (B) sagittal and T2-weighted (B) MRI showing the complete removal of the mass. The distal portion of the cord and conus medullaris, previously displaced, reveal mild swelling with T2 hyperintensity (A). MRI: magnetic resonance imaging.

On histology, the lesion was mostly composed of compact spindle cells organized in whorls and fascicles with sparse Verocay bodies. Some areas were loose-textured and showed myxoid appearance. Medium to large caliber ectatic vessels surrounded by extensive hemorrhage were present through the tumor (Fig. 2E). Small foci of coagulative necrosis were also noticed around degenerated vessels. The mitotic index was very low ( $<1$ mitosis/50 high-power field [HPF]).

On immunohistochemistry, the neoplastic cells showed strong and diffuse S-100 protein positivity. Neurofilament immunostaining showed scattered neuronal axons mainly located at the periphery of the lesion. The proliferative index (evaluated on immunohistochemistry with anti-Ki-67 antibody) was $5 \%$.

Therefore, the histologic diagnosis of hemorrhagic Schwannoma, grade I according to WHO 2016 Classification of Tumors of the Central Nervous System, ${ }^{1)}$ was rendered.

After surgical treatment, the patient still exhibited a flaccid paraplegia (L1-L2 level) with sensory level around L3, while fecal and urinary incontinence persisted. Postoperative MRI showed that the lesion was completely removed, without surgical complications (Fig. 3). After 2 weeks from surgery, the patient declared a light improvement on tactile sensitivity of the front of the thighs. She was referred to a specialized center for intensive rehabilitation.

\section{Discussion}

Acute spinal subdural hemorrhage caused by spinal schwannomas is very rare: to the best of our knowledge, 29 cases only have been previously reported in the English Literature (Table 1) ${ }^{2,4-30)}$ Most of our knowledge is based on single case reports: one series only of two cases has been reported. ${ }^{22)}$

Based on Literature data, spinal hemorrhagic schwannomas affect more frequently adult patients, with a mean age at presentation of 51 years (ranging from 11 to 74$)$. A slight female prevalence ( $\mathrm{M}: \mathrm{F}=$ 13:19) can be observed.

These hemorrhagic lesions affect almost equally the cervical spine $(24 \%),{ }^{4,5,8,11,18,25,27)}$ the lumbar tract $(24 \%), 7,13,16,17,21,22,28)$ the thoracic tract $(20 \%),{ }^{2,6,9,14,19,29)}$ and the thoraco-lumbar passage $(20 \%)^{10,12,20,22,24,26)}$ while the thoraco-cervical, ${ }^{15}$ the sacral-lumbar tract, ${ }^{30)}$ and the sacral spine ${ }^{23)}$ are more rarely involved $(12 \%)$. Bleeding can occur within the tumor $(34 \%),{ }^{6,11,12,17,22,25,26,27,28,30)}$ between the inner layer of the dura mater and the arachnoid mater of the meninges (subdural hematoma: $22 \%$ ) $^{4,5,8,9,16,18,19)}$ or into the subarachnoid space (subarachnoid hemorrhage: $16 \%)^{7,10,20,21,24)}$; multiple sites can also be involved (13\%), such as intratumoral bleeding with subdural hematoma ${ }^{2,23,29)}$ or subarachnoid hemorrhage. ${ }^{13)}$

The clinical picture is clearly different from that of spinal non-hemorrhagic schwannomas, commonly causing slowly progressive symptoms or spinal pain. Most frequent neurological symptoms at clinical presentation are acute and sudden (91\%), due to the rapid compression of neural structures by bleeding from lesion; depending on the site involved, flaccid paraplegia, pain, urinary incontinence or retention, and impaired sensitivity depict the clinical presentation. Cases that showed 
Table 1 Literature review of hemorrhagic spinal schwannoma

\begin{tabular}{|c|c|c|c|c|c|c|c|}
\hline Author & $\begin{array}{l}\text { Age/ } \\
\text { sex }\end{array}$ & $\begin{array}{l}\text { Clinical } \\
\text { features }\end{array}$ & $\begin{array}{l}\text { Duration of } \\
\text { symptoms }\end{array}$ & $\begin{array}{c}\text { Prior } \\
\text { history }\end{array}$ & $\begin{array}{c}\text { Spinal } \\
\text { level }\end{array}$ & $\begin{array}{c}\text { Enhancement } \\
\text { on MRI }\end{array}$ & $\begin{array}{c}\text { Type of } \\
\text { hemorrhage }\end{array}$ \\
\hline $\begin{array}{l}\text { Smith, } \\
1985^{4)}\end{array}$ & $74 / \mathrm{F}$ & $\begin{array}{l}\text { Cervical } \\
\text { myelopathy }\end{array}$ & Acute & Absent & Cervical & Not performed & $\mathrm{SDH}$ \\
\hline $\begin{array}{l}\text { Vazquez- } \\
\text { Barquero, } \\
1994^{5)}\end{array}$ & $68 / \mathrm{M}$ & $\begin{array}{l}\text { Urinary } \\
\text { retention, flaccid } \\
\text { paraparesis, a } \\
\text { decrease in right } \\
\text { biceps and triceps } \\
\text { jerks and a right } \\
\text { Babinski's sign }\end{array}$ & 3 days & $\begin{array}{l}\text { Severe cervical } \\
\text { and radicular } \\
\text { pain along the } \\
\text { upper limbs } \\
3 \text { days earlier }\end{array}$ & Cervical & $\begin{array}{l}\text { Peripheral bright } \\
\text { rim and central } \\
\text { isointense signal }\end{array}$ & $\mathrm{SDH}$ \\
\hline $\begin{array}{l}\text { Uemura, } \\
1998^{6)}\end{array}$ & $58 / \mathrm{F}$ & $\begin{array}{l}\text { Rapid progressive } \\
\text { weakness }\end{array}$ & Sudden onset & Absent & $\mathrm{T} 12$ & Peripheral & Intratumoral \\
\hline $\begin{array}{l}\text { Cordan, } \\
1999^{7)}\end{array}$ & $28 / F$ & $\begin{array}{l}\text { Progressive } \\
\text { paraparesis and } \\
\text { urinary retention }\end{array}$ & Subacute & $\begin{array}{l}\text { Back pain for } \\
10 \text { days }\end{array}$ & L1-L2 & N/A & $\mathrm{SAH}$ \\
\hline $\mathrm{Ng}, 2001^{8)}$ & $43 / \mathrm{M}$ & $\begin{array}{l}\text { Upper limb } \\
\text { pain and left } \\
\text { hemiparesis }\end{array}$ & 3 days & Absent & C6-7 & Homogeneous & $\mathrm{SDH}$ \\
\hline $\begin{array}{l}\text { Tanaka, } \\
2002^{9)}\end{array}$ & $26 / F$ & $\begin{array}{l}\text { Severe lower limb } \\
\text { weakness, and } \\
\text { urinary retention }\end{array}$ & Sudden onset & $\begin{array}{l}\text { Low backache } \\
\text { for } 3 \text { years }\end{array}$ & Т9-12 & Absent & $\mathrm{SDH}$ \\
\hline $\begin{array}{l}\text { Parmar, } \\
2004^{10)}\end{array}$ & $56 / \mathrm{M}$ & $\begin{array}{l}\text { Fever, neck pain, } \\
\text { altered mental } \\
\text { status, nuchal } \\
\text { rigidity, mild } \\
\text { symptoms of } \\
\text { hesitancy, and } \\
\text { poor stream of } \\
\text { urine }\end{array}$ & Acute & $\begin{array}{l}\text { Vague } \\
\text { generalized } \\
\text { backache for } \\
\text { many years }\end{array}$ & $\begin{array}{l}\text { Thora- } \\
\text { columbar } \\
\text { (T11-L1) }\end{array}$ & $\begin{array}{l}\text { Heterogeneous } \\
\text { enhancement }\end{array}$ & $\mathrm{SAH}$ \\
\hline $\begin{array}{l}\text { Kukreja, } \\
2014^{13)}\end{array}$ & $47 / \mathrm{M}$ & $\begin{array}{l}\text { Seizures and leg } \\
\text { pain }\end{array}$ & Few days & Absent & L1-2 & Heterogeneous & $\begin{array}{l}\text { Intratumoral } \\
\text { Intracranial SAH }\end{array}$ \\
\hline Zhang, 2015 ${ }^{14)}$ & $48 / \mathrm{F}$ & $\begin{array}{l}\text { Severe leg pain } \\
\text { and flaccid } \\
\text { paraplegia }\end{array}$ & 2 hours & $\begin{array}{l}\text { Low backache } \\
\text { for } 1 \text { year }\end{array}$ & $\mathrm{T} 10-11$ & N/A & N/A \\
\hline $\begin{array}{l}\text { Prasad, } \\
2016^{15)}\end{array}$ & $40 / \mathrm{M}$ & Flaccid paraplegia & 4 hours & Absent & $\mathrm{C} 7-\mathrm{T} 3$ & Absent & N/A \\
\hline $\begin{array}{l}\text { Bennet, } \\
2015^{16)}\end{array}$ & $66 / \mathrm{F}$ & $\begin{array}{l}\text { Lower extremity } \\
\text { weakness } \\
\text { and urinary } \\
\text { incontinence }\end{array}$ & 2 days & $\begin{array}{l}\text { Chronic low } \\
\text { back pain }\end{array}$ & L4 & $\begin{array}{l}\text { T1 hyperintensity, } \\
\text { T2 hypointensity, } \\
\text { without } \\
\text { enhancement }\end{array}$ & $\mathrm{SDH}$ \\
\hline $\begin{array}{l}\text { Jenkins, } \\
2015^{17)}\end{array}$ & $62 / \mathrm{M}$ & $\begin{array}{l}\text { Acute onset } \\
\text { of severe pain } \\
\text { and mild }(4 / 5) \\
\text { weakness of right } \\
\text { dorsiflexion }\end{array}$ & Sudden onset & Absent & L2-3 & $\begin{array}{l}\text { Minimal } \\
\text { enhancement }\end{array}$ & Intratumoral \\
\hline
\end{tabular}


Table 1 Continued

\begin{tabular}{|c|c|c|c|c|c|c|c|}
\hline Author & $\begin{array}{l}\text { Age/ } \\
\text { sex }\end{array}$ & $\begin{array}{l}\text { Clinical } \\
\text { features }\end{array}$ & $\begin{array}{l}\text { Duration of } \\
\text { symptoms }\end{array}$ & $\begin{array}{l}\text { Prior } \\
\text { history }\end{array}$ & $\begin{array}{l}\text { Spinal } \\
\text { level }\end{array}$ & $\begin{array}{c}\text { Enhancement } \\
\text { on MRI }\end{array}$ & $\begin{array}{c}\text { Type of } \\
\text { hemorrhage }\end{array}$ \\
\hline Sahoo, 2015 ${ }^{18)}$ & $44 / \mathrm{M}$ & $\begin{array}{l}\text { Acute } \\
\text { quadriparesis }\end{array}$ & Sudden onset & Absent & C3-C5 & Heterogeneous & $\mathrm{SDH}$ \\
\hline Hdeib, 2016 ${ }^{19)}$ & $71 / \mathrm{M}$ & $\begin{array}{l}\text { Severe lower limbs } \\
\text { weakness and } \\
\text { urinary retention }\end{array}$ & Sudden onset & Back pain & T8 & N/A & $\mathrm{SDH}$ \\
\hline Zhang, 2016 & $47 / F$ & $\begin{array}{l}\text { Symptoms } \\
\text { mimicking } \\
\text { meningitis }\end{array}$ & Subacute & $\begin{array}{l}\text { Fever and } \\
\text { headache for } 2 \\
\text { weeks }\end{array}$ & T9 & $\begin{array}{l}\text { Homogeneous } \\
\text { on T1-weighted } \\
\text { images, } \\
\text { heterogeneous } \\
\text { enhancement on T2 }\end{array}$ & $\mathrm{SAH}$ \\
\hline $\begin{array}{l}\text { Naadem, } \\
2017^{23)}\end{array}$ & $68 / F$ & $\begin{array}{l}\text { After trauma: } \\
\text { back pain, } \\
\text { lower extremity } \\
\text { weakness, } \\
\text { and urinary } \\
\text { incontinence }\end{array}$ & Sudden onset & N/A & $\begin{array}{l}\text { Conus } \\
\text { medullaris }\end{array}$ & Heterogeneous & $\begin{array}{l}\text { SDH } \\
\text { Intratumoral }\end{array}$ \\
\hline $\begin{array}{l}\text { Rahyussalim, } \\
2019^{26)}\end{array}$ & $38 / F$ & $\begin{array}{l}\text { Lower limbs } \\
\text { weakness, } \\
\text { impaired } \\
\text { sensibility, } \\
\text { defecating, and } \\
\text { urinating problems }\end{array}$ & $\begin{array}{l}2 \text { months } \\
\text { after the } \\
\text { beginning } \\
\text { of treatment } \\
\text { with only } \\
\text { joint } \\
\text { manipulation }\end{array}$ & $\begin{array}{l}\text { Difficulty } \\
\text { standing up } \\
\text { from squatting } \\
\text { positions; } \\
\text { heaviness, and } \\
\text { numbness from } \\
\text { hips radiated } \\
\text { to knees and } \\
\text { ankles for } \\
2 \text { years }\end{array}$ & $\begin{array}{l}\text { T10-T12, } \\
\text { grown to } \\
\text { T10-L2 }\end{array}$ & Hyperintensity & Intratumoral \\
\hline Jung, 201927) & $37 / \mathrm{M}$ & $\begin{array}{l}\text { Neck pain, } \\
\text { quadriparesis } \\
\text { more severe in the } \\
\text { right-side limbs, } \\
\text { decreased pain } \\
\text { sensation in the } \\
\text { left side limbs, and } \\
\text { decreased touch } \\
\text { sensation in the } \\
\text { right-side limbs }\end{array}$ & $\begin{array}{l}\text { Acute onset } \\
\text { after physical } \\
\text { therapy }\end{array}$ & $\begin{array}{l}\text { Prior clinical } \\
\text { suspicion } \\
\text { of cervical } \\
\text { myelopathy }\end{array}$ & $\begin{array}{l}\text { C2-C3, } \\
\text { extending } \\
\text { to the right } \\
\text { side of the } \\
\text { cord }\end{array}$ & $\begin{array}{l}\text { Heterogeneously } \\
\text { mixed signal } \\
\text { intensity mass and } \\
\text { mild enhancement }\end{array}$ & Intratumoral \\
\hline
\end{tabular}


Table 1 Continued

\begin{tabular}{|c|c|c|c|c|c|c|c|}
\hline Author & $\begin{array}{l}\text { Age/ } \\
\text { sex }\end{array}$ & $\begin{array}{l}\text { Clinical } \\
\text { features }\end{array}$ & $\begin{array}{l}\text { Duration of } \\
\text { symptoms }\end{array}$ & $\begin{array}{l}\text { Prior } \\
\text { history }\end{array}$ & $\begin{array}{c}\text { Spinal } \\
\text { level }\end{array}$ & $\begin{array}{c}\text { Enhancement } \\
\text { on MRI }\end{array}$ & $\begin{array}{c}\text { Type of } \\
\text { hemorrhage }\end{array}$ \\
\hline $\begin{array}{l}\text { Gotecha, } \\
2019^{28)}\end{array}$ & $61 / \mathrm{F}$ & $\begin{array}{l}\text { Chronic low } \\
\text { backache }\end{array}$ & $\begin{array}{l}3 \text { years after } \\
\text { radicular } \\
\text { symptoms }\end{array}$ & $\begin{array}{l}\text { Previous } \\
\text { radicular } \\
\text { symptoms }\end{array}$ & L3-L5 & Hyperintensity & Intratumoral \\
\hline $\begin{array}{l}\text { Dobran, } \\
2019^{29)}\end{array}$ & $38 / \mathrm{M}$ & $\begin{array}{l}\text { Lower limb plegia, } \\
\text { and urinary } \\
\text { retention }\end{array}$ & $\begin{array}{l}\text { Acute after } \\
\text { minor trauma }\end{array}$ & N/A & $\mathrm{T} 11$ & Heterogeneous & $\begin{array}{l}\text { Intratumoral, } \\
\text { SDH }\end{array}$ \\
\hline Current case & $57 / F$ & $\begin{array}{l}\text { Flaccid paraplegia, } \\
\text { impaired } \\
\text { sensibility, and } \\
\text { fecal and urinary } \\
\text { incontinence }\end{array}$ & $\begin{array}{l}\text { Less than } 24 \\
\text { hours after } \\
\text { the beginning } \\
\text { of severe } \\
\text { lumbar } \\
\text { pain and } \\
\text { right limb } \\
\text { weakness }\end{array}$ & Hypertension & $\begin{array}{l}\text { Thora- } \\
\text { columbar } \\
\text { (T11-L1), } \\
\text { arising from } \\
\text { Cauda } \\
\text { Equina }\end{array}$ & $\begin{array}{l}\text { Heterogeneous } \\
\text { enhancement }\end{array}$ & $\begin{array}{l}\mathrm{SDH} \\
\text { Intratumoral }\end{array}$ \\
\hline
\end{tabular}

N/A: not available, SAH: subarachnoid hemorrhage, SDH: subdural hemorrhage.

subarachnoid hemorrhage are likely to present findings mimicking meningitis. ${ }^{10,21,24)}$ Therefore, cerebrospinal fluid examination can be of help to differentiate meningitis from hemorrhage, in cases presenting a spinal cord mass with meningeal irritation signs (headache, fever, neck stiffness, and positive Kerning sign).

The pathogenesis of acute hemorrhage in spinal schwannomas and other spinal cord tumor, such as neurofibroma ${ }^{31)}$ or myxopapillary ependymoma, ${ }^{32)}$ is not fully understood. Two possible theories have been suggested: the vascular theory and the mechanical one. The first one supports the hypothesis that intratumoral abnormal dilated vessels may undergo a spontaneous thrombosis or rupture, resulting in bleeding. ${ }^{33,34)}$ The second theory states that movements of the spine may induce traction on tumor vessels, causing their sudden rupture. ${ }^{8,32)}$ Spinal traumas may aggravate these situations while an adjunctive risk-factor may be an anticoagulant/ antiplatelet therapy. ${ }^{27)}$

Considering the histological features of our specimen (intratumoral dilated blood vessels showing tortuous course, with fragile, hyalinized walls, and focal ischemic damage), the clinical history of the patient (no history of trauma), and the intraoperative appearance of the lesion (attached to an ectatic but intact vessel perforating the dura mater), we hypothesize that extensive bleeding might be associated with spontaneous rupture of intratumoral blood vessels. Bleeding started within the lesion at first and then involved the subdural space.
Preoperative diagnosis can be very difficult because clinical and radiological features of an hemorrhagic schwannoma are non-specific and can mimic the diagnostic picture of several lesions.

In this case, the MRI of the dorsal and lumbar spine suggested an hemorrhagic intradural extramedullary lesion.

The differential diagnosis may include vascular malformations (cavernous hemangiomas, arteriovenous fistulas), benign intramedullary tumors (ependymoma, hemangioblastoma, paraganglioma, glomic tumors), benign extramedullary neoplasms (meningiomas), and malignant tumors (metastasis). Histological examination together with a specific immunohistochemical stain panel is required for definite diagnosis and it should include epithelial (wide spectrum cytokeratins), glial (glial fibrillary acidic protein [GFAP], Olig2), meningeal (epithelial membrane antigen [EMA], Progesterone Receptor), vascular (CD34), neuroendocrine (Synaptophysin), and melanoma markers.

In conclusion, the diagnosis of a spinal hemorrhagic schwannoma, although uncommon, should be always kept in mind in case of a patient presenting with acute neurological deterioration due to a spinal intradural extramedullary bleeding involving the neural structures or the cauda equina. The definitive diagnosis is obtained only after the surgical excision of the lesion and its histological examination.

\section{Conflicts of Interest Disclosure}

The authors declare no conflict of interest regarding the present paper. 


\section{References}

1) Louis $\mathrm{DN}$, Ohgaki H, Wiestler OD, et al.: WHO Classification of Tumours of the Central Nervous System, International Agency for Research on Cancer, Lyon, 2016

2) Cohen ZR, Knoller N, Hadani M, Davidson B, Nass D, Ram Z: Traumatic intratumoral hemorrhage as the presenting symptom of a spinal neurinoma. Case report. J Neurosurg 93: 327-329, 2000

3) Wajima D, Ida Y, Inui T, Nakase H: Normal pressure hydrocephalus caused by a spinal neurinoma at the cauda equina level: a case report. Neurol Med Chir (Tokyo) 54: 423-427, 2014

4) Smith RA: Spinal subdural hematoma, neurilemmoma, and acute transverse myelopathy. Surg Neurol 23: 367-370, 1985

5) Vázquez-Barquero A, Pascual J, Quintana F, Figols J, Izquierdo JM: Cervical schwannoma presenting as a spinal subdural haematoma. Br J Neurosurg 8: 739-741, 1994

6) Uemura K, Matsumura A, Kobayashi E, Tomono Y, Nose T: CT and MR presentation of acute hemorrhage in a spinal schwannoma. Surg Neurol 50: 219-220, 1998

7) Cordan T, Bekar A, Yaman O, Tolunay S: Spinal subarachnoid hemorrhage attributable to schwannoma of the cauda equina. Surg Neurol 51: 373-375, 1999

8) Ng PY: Schwannoma of the cervical spine presenting with acute haemorrhage. J Clin Neurosci 8: 277-278, 2001

9) Tanaka H, Kondo E, Kawato H, Kikukawa T, Ishihara A, Toyoda N: Spinal intradural hemorrhage due to a neurinoma in an early puerperal woman. Clin Neurol Neurosurg 104: 303-305, 2002

10) Parmar H, Pang BC, Lim CC, Chng SM, Tan KK: Spinal schwannoma with acute subarachnoid hemorrhage: a diagnostic challenge. AJNR Am J Neuroradiol 25: 846-850, 2004

11) Ciappetta P, D’Urso PI, Colamaria A: Giant craniovertebral junction hemorrhagic schwannoma: case report. Neurosurgery 62: E1166; discussion E1166, 2008

12) Ichinose $T$, Takami $T$, Yamamoto $N$, Tsuyuguchi $N$, Ohata K: Intratumoral hemorrhage of spinal schwannoma of the cauda equina manifesting as acute paraparesis--case report. Neurol Med Chir (Tokyo) 49: 255-257, 2009

13) Kukreja S, Ambekar S, Sharma M, Nanda A: Cauda equina schwannoma presenting with intratumoral hemorrhage and intracranial subarachnoid hemorrhage. J Neurosurg Spine 21: 357-360, 2014

14) Zhang HZ, Li Y, Han Y, et al.: Spontaneous acute hemorrhage of intraspinal canal cellular schwannoma with paraplegia: A case report. Br J Neurosurg 29: 425-427, 2015

15) Prasad GL, Kongwad LI, Valiathan MG: Spinal intradural schwannoma with acute intratumoural haemorrhage: case report and review. J Clin Diagn Res 10: PD01-03, 2016
16) Bennett SJ, Katzman GL, Mehta AS, Ali S: Hemorrhagic schwannoma presenting with subarachnoid hemorrhage and resulting cauda equina syndrome. Spine J 15: e17-18, 2015

17) Jenkins AL 3rd, Ahuja A, Oliff AH, Sobotka S: Spinal schwannoma presenting due to torsion and hemorrhage: case report and review of literature. Spine J15: e1-4, 2015

18) Sahoo RK, Das PB, Sarangi GS, Mohanty S: Acute hemorrhage within intradural extramedullary schwannoma in cervical spine presenting with quadriparesis. J Craniovertebr Junction Spine 6: 83-85, 2015

19) Hdeib A, Goodwin CR, Sciubba D, et al.: Hemorrhagic thoracic schwannoma presenting with intradural hematoma and acute paraplegia after spinal manipulation therapy. Int J Spine Surg 10: 42, 2016

20) Zhang J, Huang Y, Meng Y, He X, Yang J, Hao D: Spinal schwannoma hemorrhage manifesting as acute paraplegia. Spine J 10: e667-e668, 2016

21) Zhang HM, Zhang YX, Zhang Q, Song SJ, Liu ZR: Subarachnoid hemorrhage due to spinal cord schwannoma presenting findings mimicking meningitis. J Stroke Cerebrovasc Dis 25: e123-125, 2016

22) Kimura R, Miyakoshi N, Suzuki T, et al.: Traumatic intratumoral hemorrhage of schwannoma of the cauda equina: a report of two cases. J Orthop Sci 23: 1105-1109, 2018

23) Nadeem M, Mansoor S, Assad S, Ilyas F, Qavi AH, Saadat S: Spinal schwannoma with intradural intramedullary hemorrhage. Cureus 9: e1082, 2017

24) Tanki H, Singh H, Raswan US, et al.: A rare case of spinal schwannoma in a child presenting with subarachnoid hemorrhage: a case report with review of literature. J Pediatr Neurosci 13: 503-507, 2018

25) Gandhoke CS, Syal SK, Singh D, Batra V, Nallacheruvu Y: Cervical C2 to C4 schwannoma with intratumoral hemorrhage presenting as acute spastic quadriparesis: a rare case report. Surg Neurol Int 9: 142, 2018

26) Rahyussalim AJ, Wisnubaroto RP, Kurniawati T, Latsarizul ASB, Chairani N: Hemorrhagic spinal schwannoma in thoracolumbar area with total paraplegia. Case Rep Med 2019: 7190739, 2019

27) Jung GS, Lee YM, Kim YZ, Kim JS: Intratumoral hemorrhage of the cervical spinal schwannoma presenting: acute quadriparesis. Brain Tumor Res Treat 7: 160-163, 2019

28) Gotecha S, Punia P, Patil A, et al.: A rare chronic presentation of schwannoma with hemorrhage. Asian J Neurosurg 14: 897-900, 2019

29) Dobran M, Nasi D, Della Costanza M, Formica F: Intralesional and subarachnoid bleeding of a spinal schwannoma presenting with acute cauda equina syndrome. BMJ Case Rep 12: e229251, 2019

30) Ito K, Ando K, Kobayashi K, et al.: Natural reduction in acute intratumoral hemorrhage of spinal schwannoma in the cauda equina. Nagoya J Med Sci 81: 701705, 2019 
31) Lee ST, Lui TN: Acute paraplegia resulting from haemorrhage into a spinal neurofibroma. Paraplegia 30: 445-448, 1992

32) Argyropoulou PI, Argyropoulou MI, Tsampoulas C, Gogos P, Manavis I, Efremidis SC: Myxopapillary ependymoma of the conus medullaris with subarachnoid haemorrhage: MRI in two cases. Neuroradiology 43: 489-491, 2001

33) Mills B, Marks PV, Nixon JM: Spinal subarachnoid haemorrhage from an "ancient" schwannoma of the cervical spine. Br J Neurosurg 7: 557-559, 1993
34) Luxon LM, Harrison MJ: Subarachnoid hemorrhage and papilledema due to a cervical neurilemmoma. Case report. J Neurosurg 48: 1015-1018, 1978

Corresponding author: Viscardo P. Fabbri, MD, PhD Department of Biomedical and Neuromotor Sciences, University of Bologna, Unit of Anatomic Pathology at Bellaria Hospital, via Altura 3, Bologna, Italy. e-mail: viscardopaolo.fabbr2@unibo.it 